\title{
ARCHITECTURAL REVIEW AND CONCEPTUAL DEVELOPMENT OF FACULTY INFORMATION SYSTEM "KPI-CONNECT"
}

\section{A. KLYMENKO, Y. P. BUTSKYI, K. M. HRYSHCHENKO, M. H. SIVACHENKO, V. V. KRYVETS, D. A. KRYVOSHEI, D. T. NGUEN}

\begin{abstract}
This paper is dedicated to development model of information system to automate educational process based on the Faculty of Informatics and Computer Science at NTUU "Igor Sikorsky Kyiv Polytechnic Institute". Existing educational systems of different higher education institutions had been studied; main realized functions of similar platforms were defined. As a result of research model, that enables insertion of students, teachers and other university personnel data, storing personal data and information about users' scientific works, and also is able to be integrated into existing university information space, has been obtained.
\end{abstract}

Keywords: educational process, information system, automatization, practical use.

\section{Introduction}

Information system of educational process automatization allows to solve one key issue of informational technologies integration. We are suggesting simple and effective approach to building powerful educational process automatization system, and also demonstrating practical usage aspect in different educational process - that is the goal of this research paper.

Product examination includes forming base system structure, introducing new information solutions, that will allow maximum automatization of documents insertion process performed by teachers, will include effective feedback mechanism. will enable platform integration into modern social networks and the Faculty of Informatics and Computer Science at NTUU "Igor Sikorsky Kyiv Polytechnic Institute" information space - that lets simple and accessible connection between system users.

\section{References analysis and work perspective}

It is hard to integrate modern technologies into different life aspects in the world full of developed computer systems. In the area of education, it is very important to create automated user control system with possibility of effective usage in educational, documentation preparations processes [10]. Informational technologies usage allows creation such a powerful system, that greatly simplifies mechanism of educational process management in educational institutions [6]. Apart from that, mass usage of similar systems enables more effective educational process of modern youth, that is greatly digitalized, and also simplifies access to scientific works of many authors, which might unite education and tuition into a single management process [16]. This might become a revolution in modern education perception [12]. 
Let's examine some examples of information educational management systems from different universities around the globe.

Work [18] presents multiple educational platforms of Russian educational institutions. Some examples of these systems are "Educational process quality management. Performance and attendance accounting" of Samara State Technical University, "Electronic university" of Kazan Federal University etc. Each of these systems realized only a part of base functionality, required for university work organization within separate information space. Most notable among them are platform for accounting students' attendance and performance, subjects lists and corresponding curriculums formation, automatic time schedule generation based on tutors' load [4, 7, 8].

Among other examples of introducing information educational management systems are multiple platforms developed in USA, e.g., information system from University of Colorado Boulder named "MyCUinfo". In comparison to Russian information systems, such platforms have very similar students' educational process management, but also has a list of additional functions that includes finances management, personal library access etc [15].

\section{Research goals and tasks}

This paper has a goal of information system to provide faculty with means of educational process automation architecture analysis and building. This also includes analysis and evaluation model of current provisions on educational process in at NTUU "Igor Sikorsky Kyiv Polytechnic Institute" for using it as a base for architecture creation.

Such a model requires according realization approach within some information system, that will be available for each educational process party: students, tutors, educational institution structural units etc. Another important factor is which software tools allow building a platform based on own model. Examination of such structural components is a task of this paper.

\section{Research data and methods}

Building effective educational process automatization involves solving multiple important problems. First of all, system should use modern information technology software tools to enable fast system access for each user, and also will effectively solve simultaneous access of significant users count. Secondly, this system should realize traditional information system creation model, which will serve as a base for different components to function properly. Thirdly, system should follow existing principles of educational process organization within specific educational institution.

Realization of this information system should take into consideration scalability issue, as users and database records count growth might lead to general system performance regression. Among other existing methods of computer systems scaling, the most suitable for current approach is horizontal scaling. During building distributed model system, which might be easily parallelized between different hardware units using containerization technologies and approach of creation modules as different 
services, usage of such a technique will allow ease of scalability to support growing users and requests count [2].

Accordingly, the central system component is relational database, which enables effective data storage in tables, its view and modification in different parts of system through internal database connections. PostgreSQL was the choice of a specific SQLlike database management system, which is fast and powerful open-source solution with possibility to scale up or out as a result of an increase in users or requests count. Main system software component, that also serves as connection to database, is built using modern version of PHP programming language with application of Symfony framework, that uses MVC pattern while preserving SOLID principles during development cycle. Frontend interface of platform will be written in JavaScript, which is the most popular browser programming language, with framework React, that has lost of pre-build forms and components to use.

Apart from listed components realization, this platform will allow getting feedback between systems users. For this purpose, the most popular social networks (e.g., Telegram, Facebook, Linkedin etc) will be integrated. Also, it is important to note, that platform should have relations with other university websites and information systems, and ideally these relations would be bidirectional. Thus, such a product will allow new program complex integration into a indivisible information space of faculty or even university in general.

As a result, system model is presented on fig. 1.

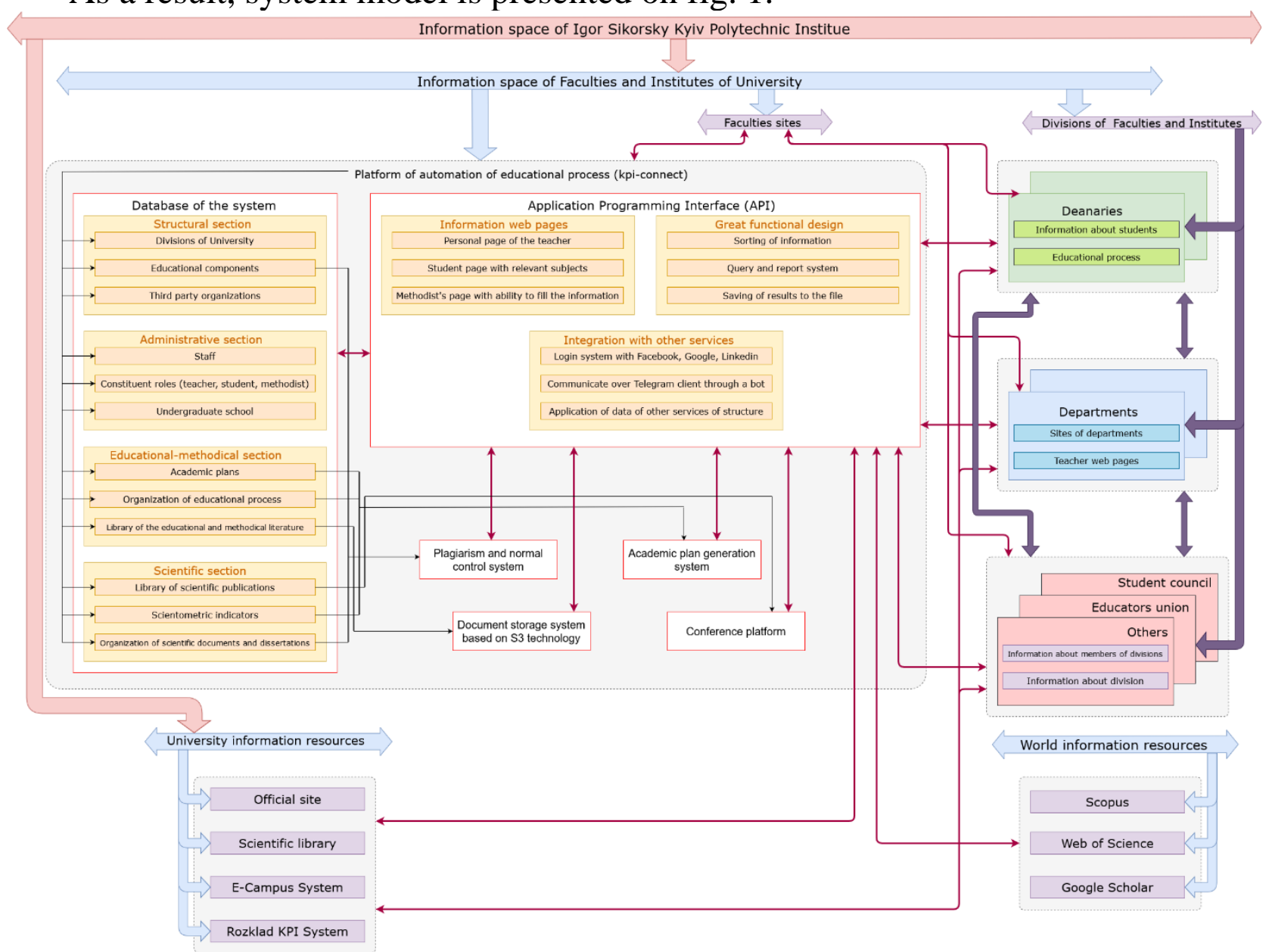

Fig. 1. High-level system structure and relations with university information space 


\section{Research results}

Applying platform description from fig. 1 development of individual system components was performed in accordance with general structure. Also, as a result of research, it is possible to define practical usage of each separate component, that is a part of global platform.

According to platform description, four main components may be highlighted, that are main parts of system. However, they are not the only ones allowed as system anticipates usage of additional components that distinguish it among other similar products.

Connection between database and system users is performed through API (Application Programming Interface). Its goal is to provide convenient access to information, that is stored in database, and also to allow effective and simple management of it and additional system capabilities.

According to description, let's define system sections as follows.

\subsection{Structural section}

Structural section of platform is responsible for building educational structure within university. Presented entities enable university components hierarchy creation in accordance to principles of educational process at NTUU "Igor Sikorsky Kyiv Polytechnic Institute" [17]. It is possible to design and realize a base for university educational components using given entities.

Structural section organization model is illustrated on fig. 2 . 


\section{Structural section}

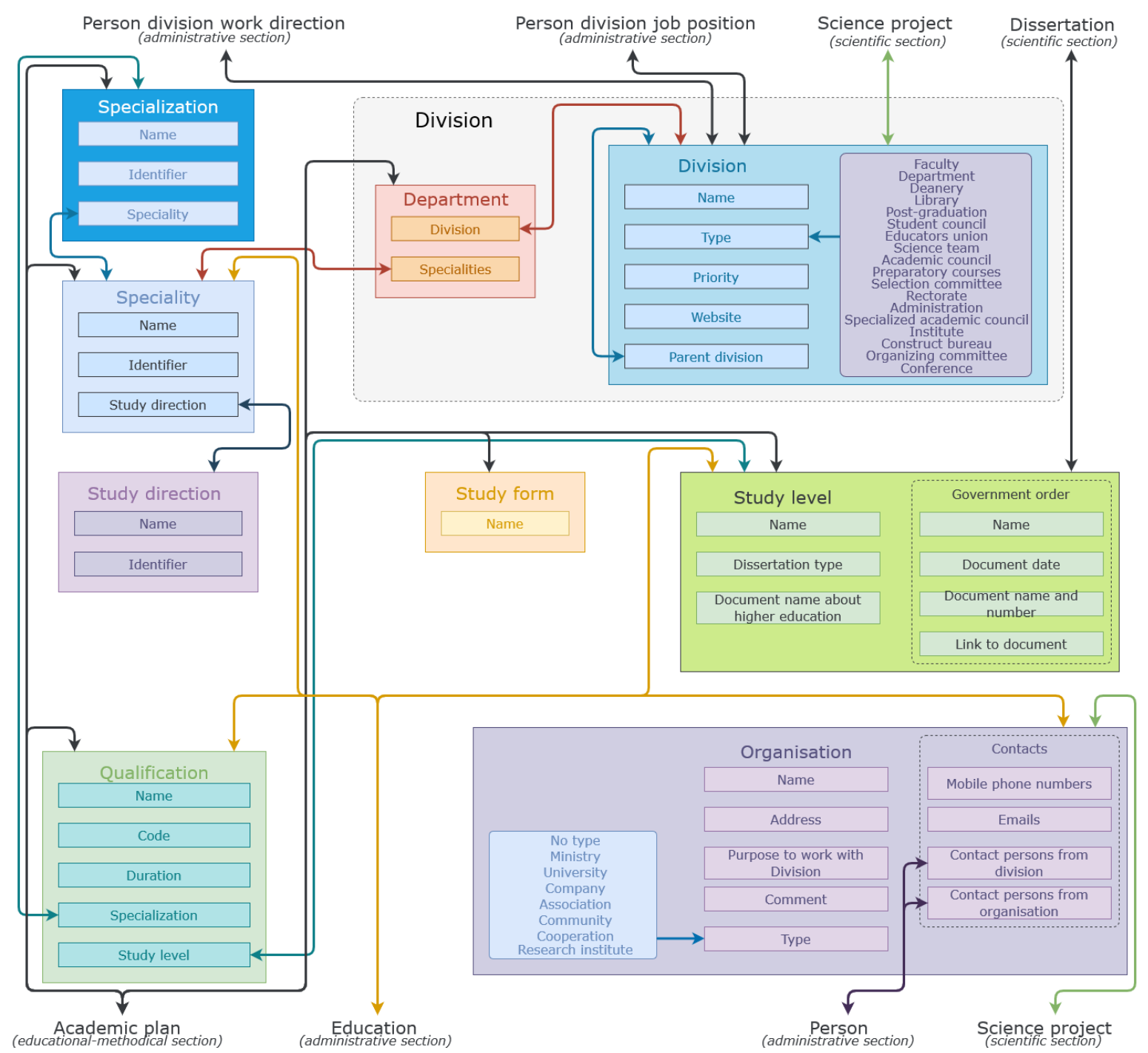

Fig. 2. Structural section of platform

\subsection{Administrative section}

Administrative section of platform forms personnel structure, which is base unit working with platform. This section describes base entity of Person, and key roles of system users - Student and Tutor. Interaction of Person and different parts of platform is defined within connections of current section entities.

Thus, we're having administrative section organization model on fig. 3 . 


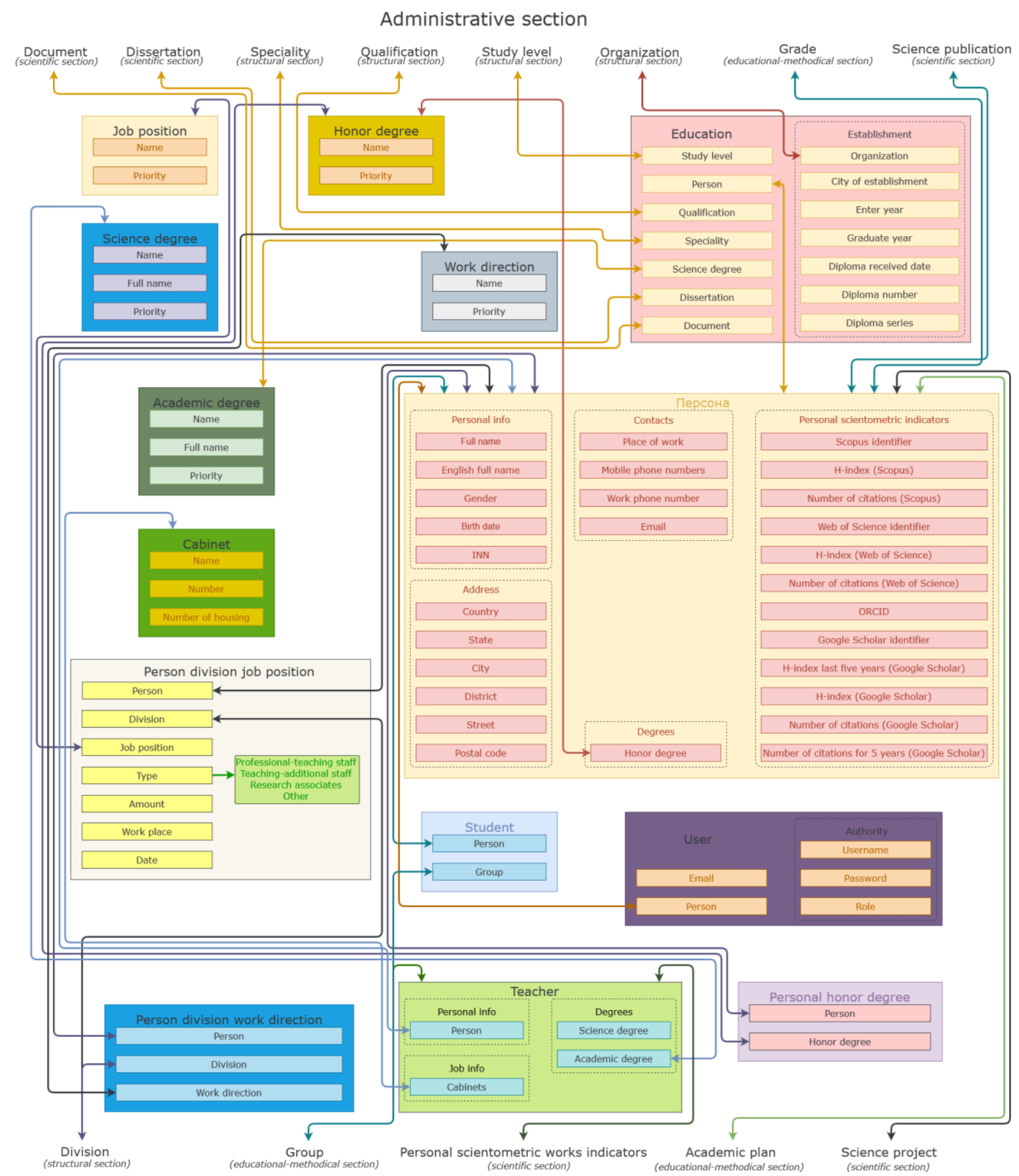

Fig. 3. Administrative section of system

\subsection{Educational-methodical section}

This section of system is responsible mainly for curriculum realization. Main component of this section is Curriculum (presented as Academic Plan), which is a base for planning subjects both for Students and for Tutors. Another component is Group, which unites Students, Subjects and Grades through Curriculum.

Educational-methodical section organization model is presented on fig. 4. 


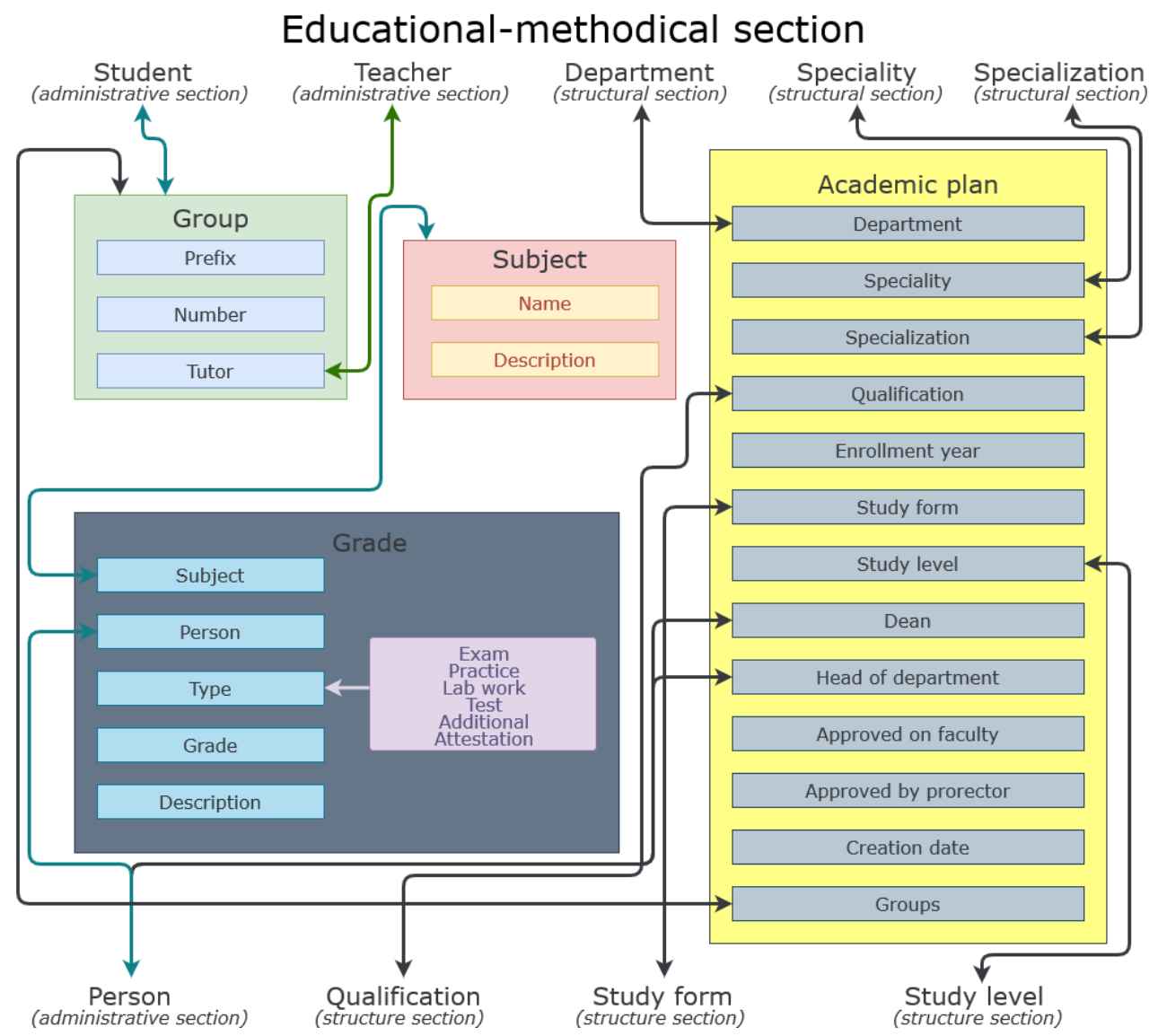

Fig. 4. Educational-methodical section of system

\subsection{Scientific section}

Scientific section is responsible for scientific publications structure, and also for storing students' dissertations. Important component here is object storage, which performs uploading and storing documents inside of the system. Due to the nature of these files, it is unadvisable to keep them in traditional databases (both relational and NoSQL types) as it is relatively hard to effectively store and retrieve them, while their usually bigger size would mean additional load to the main component of the whole system. Apart from documents, other entities in this section include information of scientometric indicators of university tutors with possibility to extend them.

Scientific section organization model is presented on fig. 5. 


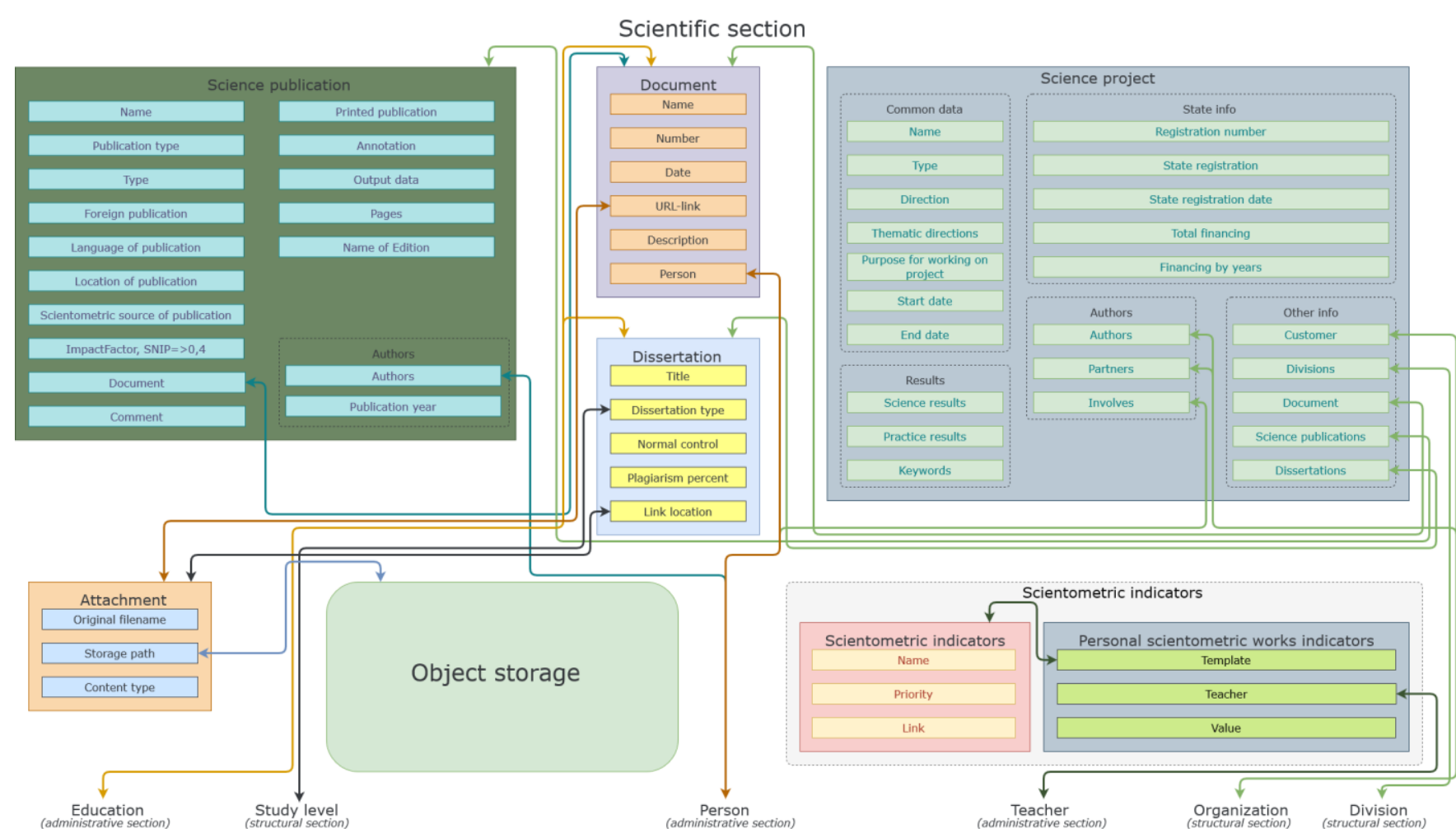

Fig. 5. Scientific section of system

\section{Conclusions}

Using faculty educational process automatization information system "KPIConnect" has a number of advantages. First of all, described system implies dependent sequential structure Study direction - Specialty - Specialization and practically connected Qualification. Such an organization allows development of separate entity of Curriculum/Academic plan with possibility to develop automatic generation algorithm in future. Secondly, each key system component provides a possibility to create and generated highly convoluted entities based on universal entity of Person, then assign specific role to it, which will regulate available and visible information from user perspective. In virtue of this personnel organization, it is possible to uniquely and independently control each Person's educational process. Thirdly, research involves designing and forming unified compound structure of Curriculum (Academic plan) - it combines Student, Tutor, Subject and Grade through single data entity, that creates fast and flexible connections between Tutor and Student: the first one is able to conveniently store big amounts of educational process information, the latter is able to retrieve only relevant parts of it.

Apart from that, obtained structure fully complies with principles of educational process organization at NTUU "Igor Sikorsky Kyiv Polytechnic Institute". As a result of that, such system can complement educational process and help with its management. And finally, object storage organization enables means to automate process of checking dissertations and scientific papers for plagiarism and compliance with formal requirements with appropriate systems. 


\section{References}

1. Amazon Simple Storage Service: User Guide. [Electronic resource] // Amazon Web Services, Inc. $\quad-\quad 2021$ - $\quad$ - $\quad$ access mode: https://docs.aws.amazon.com/AmazonS3/latest/userguide/s3-userguide.pdf

2. Banks, E. What does "scale out" vs. "scale up" mean? [Electronic resource]. / Ethan Banks // Packet Pushers Interactive LLC. - 2017. - access mode: https://packetpushers.net/scale-up-vs-scale-out/

3. Bondi, A. B. Characteristics of scalability and their impact on performance [Electronic resource]. / Bondi, André B. // WOSP '00: Proceedings of the 2nd international workshop on Software and performance. - 2000. - Ottawa, Ontario, Canada - pp. 195-203. - access mode: https://doi.org/10.1145/350391.350432

4. Evdokimov, M. A., Mishhenko, A. G. Information system for operational monitoring of students' progress and attendance. Development and implementation experience [Electronic resource]. / M. A. Evdokimov, A. G. Mishhenko // Vestnik Samarskogo gosudarstvennogo tehnicheskogo universiteta. Serija: Psihologopedagogicheskie nauki. - 2010. - pp. 49-54. - access mode: https://cyberleninka.ru/article/n/informatsionnaya-sistema-operativnogokontrolya-uspevaemosti-i-poseschaemosti-studentov-opyt-razrabotki-ivnedreniya/viewer

5. Gehlawat, M. School Management Information System: An Effective Tool for Augmenting the School Practices [Electronic resource]. / Dr. Manju Gehlawat // New Frontiers in Education: International Journal of Education \& Research. - 2014. 47. access mode: https://www.researchgate.net/publication/315380267_School_Management_Infor mation_System_An_Effective_Tool_for_Augumenting_the_School_Practices

6. Gorjunov, V. S. Information systems in education [Electronic resource]. / V. S. Gorjunov // Molodoj uchenyj. - 2010. - №5(16) - T. 2. - pp. 159-161. - access mode: https://moluch.ru/archive/16/1540/

7. Gostev, V. M., Latypov R. H. Educational information environment of the Faculty of CMC of Kazan Federal University: the experience of formation and development [Electronic resource]. / V. M. Gostev, R. H. Latypov // Sovremennye informacionnye tehnologii i IT-obrazovanie. -2010 . - pp. 220-225. - access mode: https://cyberleninka.ru/article/n/obrazovatelnaya-informatsionnaya-sredafakulteta-vmk-kazanskogo-federalnogo-universiteta-opyt-formirovaniya-irazvitiya/viewer

8. Gur'janova T. N., Karimova L. K. The use of information systems in the educational, scientific and administrative activities of the university (on the example of Kazan Federal University) [Electronic resource]. / T. N. Gur'janova, L. K. Karimova // Vestnik Kazanskogo tehnologicheskogo universiteta. - 2014. - pp. 381-383. - access mode: https://cyberleninka.ru/article/n/primenenieinformatsionnyh-sistem-v-obrazovatelnoy-nauchnoy-i-adminictrativnoydeyatelnosti-vuza-na-primere-kfu/viewer

9. Hataeva, R. S. Structural components of an automated management system of a modern innovative university [Electronic resource]. / Rovsan Hataeva // Vestnik 
universiteta. - 2015 . - №5. - $\quad$ - access mode: https://cyberleninka.ru/article/n/strukturnye-komponenty-avtomatizirovannoysistemy-upravleniya-sovremennogo-innovatsionnogo-vuza/viewer

10.Levenson, N., Boser, U. The Promise of Education Information Systems. How Technology Can Improve School Management and Success [Electronic resource]. I Nathan Levenson, Ulrich Boser // Center for American Progress. - 2014. - 25 p. access mode: https://files.eric.ed.gov/fulltext/ED561090.pdf

11.Levy, J. Management Information Systems in Education [Electronic resource]. I Jocelyn Levy // Iris Software Group Ltd. - 2020. - access mode: https://www.iris.co.uk/blog/management-information-systems-in-education/

12. Montoya, S. Why We Need Effective Education Management Information Systems [Electronic resource]. / Silvia Montoya // UNESCO Institute of Statistics. - 2018. - access mode: http://uis.unesco.org/en/blog/why-we-need-effective-educationmanagement-information-systems

13. Musty K. S. S. Management Information Systems for Higher Education Institutions: Challenges and Opportunities [Electronic resource]. / Michael Sony, Kochu Therisa Kariganda, Neeta Baporikar // Quality Management Implementation in Higher Education: Practices, Models and Case Studies. - 2020. - Hershey, PA: IGI Global - pp. 110-131. - access mode: https://doi.org/10.4018/978-1-5225-9829-9.ch006

14. MyClarion Student Information System [Electronic resource] // Clarion University. - access mode: https://www.clarion.edu/about-clarion/computingservices/myclarion/index.html

15.myCUinfo Available Features [Electronic resource] // University of Colorado Boulder. - access mode: https://spot.colorado.edu/ mycuinfo/help/features.html

16.Nussbaum-Beach, S. A Futuristic Vision for 21st Century Education [Electronic resource]. / Sheryl Nussbaum-Beach // ASCD Express. - 2011. - №11(6). - access mode: http://web.archive.org/web/20201105231857/http://www.ascd.org/ascdexpress/vol6/611-nussbaum-beach.aspx

17.Regulations on the organization of the educational process in Igor Sigorsky Kyiv Polytechnic Institute [Electronic resource]. / NTUU KPI im. Ighorja Sikorsjkogho - decree №7/124. - Official publication. - B.: 2020. - p. 17. - access mode: https://document.kpi.ua/files/2020_7-124.pdf

18.Senkin, V. V. Possibilities of information systems in education management [Electronic resource]. / V. Senkin // Vestnik Juzhno-Ural'skogo gosudarstvennogo universiteta. Serija: Obrazovanie. Pedagogicheskie nauki. - 2012. - №41(18). - pp. 42-45. - access mode: https://cyberleninka.ru/article/n/vozmozhnostiinformatsionnyh-sistem-v-upravlenii-obrazovaniem/viewer 